\title{
GROWTH FEATURES OF THE AMUR SLEEPER, PERCCOTTUS GLENII (ACTINOPTERYGII: PERCIFORMES: ODONTOBUTIDAE), IN THE INVADED CARPATHIAN BASIN, HUNGARY
}

\author{
Krisztián NYESTE, Sára KATI, Sándor A. NAGY, and László ANTAL* \\ Department of Hydrobiology, University of Debrecen, Debrecen, Hungary
}

\begin{abstract}
Nyeste K., Kati S., Nagy S.A., Antal L. 2017. Growth features of the Amur sleeper, Perccottus glenii (Actinopterygii: Perciformes: Odontobutidae), in the invaded Carpathian Basin, Hungary. Acta Ichthyol. Piscat. 47 (1): 33-40.
\end{abstract}

Background. The Amur sleeper, Perccottus glenii Dybowski, 1877, is the most invasive alien fish species in the native aquatic communities in central Europe. Although the accelerated invasion of $P$. glenii has been well documented, there is little information on the ecological and growth parameters of non-native populations in this region. The aim of this study was to describe the growth features of the population of P. glenii in a shallow oxbow lake in the Carpathian Basin.

Materials and methods. Our study sample consisted of 1239 individuals $(628 \hat{\jmath}+611$ o) collected from an oxbow lake near the Tisza River in the same month for three years (2013-2015). The length, weight, age structure, sex-dependent growth rate, and the condition factor of the collected specimens were determined.

Results. The sex ratio was $0.49\left(q \div\left(q+\zeta^{\top}\right)\right)$. The standard length and weight of the collected $P$. glenii specimens ranged from 20.7 to $127.7 \mathrm{~mm}$ and from 0.3 to $75.8 \mathrm{~g}$, respectively. The length-weight relations (SL- $W$ ) were allometrically negative for the males $\left(W=3.2 \times 10^{-5} \mathrm{SL}^{2.960}\right)$, females $\left(W=3.8 \times 10^{-5} \mathrm{SL}^{2.921}\right)$, and both sexes $(W=$ $\left.3.5 \times 10^{-5} \mathrm{SL}^{2.940}\right)$, without significant differences between males and females. According to the length-frequency analysis, five age groups were differentiated. The von Bertalanffy growth models were $L_{\infty}=138.87 \mathrm{~mm}, k=0.21$, $t_{0}=-0.54(\lesssim), L_{\infty}=174.21 \mathrm{~mm}, k=0.17, t_{0}=-0.33(q), L_{\infty}=154.01 \mathrm{~mm}, k=0.19, t_{0}=-0.45(\hat{\jmath}+q)$. The growth performance parameters were $\Phi^{\prime}=3.61(\hat{\partial}), \Phi^{\prime}=3.71(\uparrow), \Phi^{\prime}=3.65(\hat{\jmath}+\uparrow)$, respectively.

Conclusion. Due to unequal investment in reproduction, there was a significant difference in the growth rate between males and females. The literature data showed that invasive gobies and odontobutids (e.g., $P$. glenii) exhibit more opportunistic reproduction strategy in newly colonized areas, which may contribute to the invasion success. This strategy (e.g., earlier maturation, longer spawning period, etc.) results in slower growth rate due to energetic trade-off between reproduction and somatic growth. The observed growth rate of invasive Amur sleeper population (especially in the older age groups) was slower than that of native and more established naturalized populations in Eurasia.

Keywords: age, growth, condition factor, rotan, invasion

\section{INTRODUCTION}

Invasive species are causing serious negative consequences for their new environment because they can alter the entire habitat and ecosystem functioning, by displacing native species and these processes have significant economic impacts (Copp et al. 2005, Vilà et al. 2010, Ferincz et al. 2016). The success of an alien invasive species depends on its high environmental tolerance and its life-history traits (Grabowska and Przybylski 2015). Therefore, in order to conserve the biodiversity, it is very important to investigate the ecology of invasive species (Erős 2005, Grabowska et al. 2011, Grabowska and Przybylski 2015, Kati et al. 2015).
The Amur sleeper, Perccottus glenii Dybowski, 1877, also known as rotan or Chinese sleeper is one of the most invasive freshwater fishes in Eurasia (Copp et al. 2005, Reshetnikov and Ficetola 2011, Reshetnikov 2013). The native range of $P$. glenii covers the Russian Far East, north-eastern China, and the northern part of the Korean Peninsula (Berg 1949, Nikolskij 1956, Bogutskaya and Naseka 2002). Amur sleeper appeared in western regions of Eurasia in 1916 and it has been spreading very fast in eastern and central Europe (Reshetnikov 2004, Reshetnikov et al. 2017). The first occurrence of Amur sleeper in the Danube River system was observed in Hungary from the Lake Tisza (Kisköre Reservoir) at Tiszafüred in 1997 (Harka 
1998). Nowadays $P$. glenii is widely established along the Tisza River and its tributaries (Harka et al. 2003) and it was found in canals located closely to Lake Balaton (Erös et al. 2008), middle section of the Danube River basin (Takács and Vitál 2012), and the drainage system of the Drava River (Takács et al. 2015). In 2013 the species appeared in the upper part of the Danube River basin in Bavaria, Germany (Reshetnikov and Schliewen 2013, Nehring and Steinhof 2015). Reshetnikov and Karyagina (2015) have reported the long-term existence of a stable population of P. glenii in a lake in Naturschutzgebiet Charlottenhofer Weihergebiet in Germany

The Amur sleeper prefers lentic waters, canals, lakes, ponds, backwaters, and bogs with dense submerged vegetation (Kottelat and Freyhof 2007). The abundance of the species can increase rapidly in these habitats (Bogutskaya and Naseka 2002, Harka et al. 2003). Amur sleeper is a very effective predator of a wide range of aquatic animal species at all trophic levels. It mainly consumes macroinvertebrates, eggs, and even larvae and juveniles of fishes and amphibians (Reshetnikov 2003, Koščo et al. 2008, Grabowska et al. 2009, Kati et al. 2015). Many studies have reported a negative correlation between the abundance of $P$. glenii and that of native fishes (e.g., Rešetnikov 2001, Reshetnikov 2003, Koščo et al. 2003a).

The human-mediated factors (e.g., aquarists, anglers, and cyprinid stocking) are important only in the first stage of introduction (Reshetnikov 2004, Grabowska et al. 2011). The species has spread from the initial areas of introduction relatively fast and successfully due to its biological features (Bogutskaya and Naseka 2002, Reshetnikov 2004, Grabowska et al. 2011). However, there are great variations between the populations in their life-history traits as a result of variable local environmental conditions (Grabowska et al. 2011, Fox and Copp 2014). It has been reported, that $P$. glenii populations exhibit more opportunistic traits (e.g., earlier maturity and higher fecundity of females, longer spawning season) in their introduced central European range than in their introduced east European and native range (Grabowska et al. 2011). The success of the Amur sleeper in the early invasion stage (even populations in central Europe) depends on the higher investment in reproduction, but this energy allocation leads to decrease in growth rate due to energetic tradeoff between reproduction and somatic growth (Kozłowski 1996, 2006, Grabowska et al. 2011).

Studies focusing on the growth of the Amur sleeper in central Europe are underrepresented in the literature, despite the high-risk expansion of the species (Koščo et al. 2003b, Grabowska et al. 2011). Our previous study about growth features of $P$. glenii in the middle Tisza region revealed no significant differences between populations of five sampling sites, including Rakamazi-Nagy-morotva (RNM) (Harka et al. 2012). The RNM is a shallow oxbow lake near the Tisza River with a length of $4.4 \mathrm{~km}$, a mean width of $200 \mathrm{~m}$, and a mean depth of $1.8 \mathrm{~m}$. RNM is a suitable habitat for Amur sleeper characterized by dense areas of submerged, floating and emergent vegetation (mainly Stratoides aloides, Hydrocharis morsus-ranae, Ceratophyllum demersum, Ceratophyllum submersum, Phragmites australis, Potamogeton sp., Lemna sp.). Since the Amur sleeper is one of the most abundant fish species of the oxbow lake, the aim of the presently reported study was to describe the:

- Age structure;

- Sex-dependent growth rate;

- Condition

of $P$. glenii population in RNM, Hungary, central Europe.

\section{MATERIAL AND METHODS}

A total of 1239 specimens of the Amur sleeper were collected in RNM (coordinates: $48^{\circ} 05^{\prime} 45.2^{\prime \prime} \mathrm{N}$, $21^{\circ} 27^{\prime} 45.8^{\prime \prime} \mathrm{E}$ ) by electrofishing (Hans Grassl IG200/2b, PDC, 75-100 Hz, 350-650 V, max. power output $10 \mathrm{~kW} /$ impulse, Hans Grassl GmbH, Germany) at the end of vegetation period in November 2013, 2014, and 2015. Fish individuals were euthanized with an overdose of clove oil and preserved in 5\% (V/V) formaldehyde.

Standard length (SL), total length (TL), and body weight $(W)$ of fish were measured using digital calliper (to the nearest $0.01 \mathrm{~mm}$ ) and digital analytical laboratory scale (to the nearest $0.01 \mathrm{~g}$ ), respectively. Sex determination was performed by direct observation of gonads. Sex ratio was expressed as a proportion of females to all specimens $(q \div(q+\widehat{\zeta}))$, and tested with Chi-squared analyses $\left(\chi^{2}\right)$. The relation between SL and TL was calculated by linear regression

$$
\mathrm{TL}=a+b \mathrm{SL}
$$

Based on log-converted weight and standard length, the parameters $a$ and $b$ of the length-weight regression analysis were calculated according to the equation (Le Cren 1951, Froese et al. 2011)

$$
\ln W=\ln (a)+\ln (b) \mathrm{SL}
$$

and expressed as

$$
W=a \mathrm{SL}^{b}
$$

The Student's $t$-test was used to test the allometry in growth (Zar 2010). Analysis of Covariance (ANCOVA) was performed to test for differences in the length-weight relations between sexes (Zar 2010). Logarithmic transformation was used to improve the normality of data.

The age groups were determined using the Petersen method (Tesch 1968) based on the length-frequency distribution with each high peak representing a separate age group (Tesch 1968). Descriptive statistics of age groups were calculated by the Bhattacharya method (Bhattacharya 1967) using FiSAT software (Gayanilo et al. 2005). The Bhattacharya method was not applicable in case of $5+$ and $6+$ age groups due to the small number of individuals of these groups. Therefore those data were not included in the statistical evaluations and were mentioned as informative 
aspect only. Subsequently, individuals representing mean standard length of each age group and sex were subjected for scale ageing procedure (using criteria of Tesch (1968)) as a verification of our calculation. Kolmogorov-Smirnov two-sample test was used to compare the size frequency distribution between males and females. A two way Analysis of Variance (ANOVA) was performed involving individuals representing mean SL of age groups $\pm 5 \mathrm{~mm}$ (426 males and 394 females) to test statistical differences in size distribution according to age and sex (Zar 2010).

Fulton's equation (Fulton 1911, Froese 2006) was used to calculate the condition factor for each individual

$$
K=100 \mathrm{WSL}^{-3}
$$

The von Bertalanffy growth model (VBGM)

$$
L_{t}=L_{\infty}\left(1-\exp \left(-k\left(t-t_{0}\right)\right)\right)
$$

was applied for mathematical description of growth (von Bertalanffy 1934, Ricker 1975) using FiSAT software (Gayanilo et al. 2005). Since the von Bertalanffy equation's $k$ parameter is negatively related to $L_{\infty}$, as much as rapid rate of population growth (the highest $k$ ) was faster, so $L_{\infty}$ was smaller and vice versa (Raikova-Petrova et al. 2011), therefore a phi-prime $\left(\Phi^{\prime}\right)$ parameter (Munro and Pauly 1983) were calculated as indices of growth performance

$$
\Phi^{\prime}=\log _{10}(k)+2 \log _{10}\left(L_{\infty}\right)
$$

Since the $\Phi^{\prime}$ parameter can only provide qualitative information, therefore it is not appropriate to be used for comparisons of growth rate (Živkov et al. 1999), analysis of the residual sum of squares (ARSS) was performed to compare VBGMs between the sexes (Chen et al. 1992).

Past 3.03 (Hammer et al. 2001), IBM SPSS Statistics for Windows (Version 20.0), Statistica 12.0*, and Microsoft Excel 2013 software were used for statistical evaluation of our data.

\section{RESULTS}

A total of 628 individuals were identified as males and 611 as females. The sex ratio was 0.49 . A chi-square revealed no significant deviation from the theoretical $1 \div$ 1 sex ratio $\left(\chi^{2}=0.75, \mathrm{DF}=1, P>0.05\right)$. The respective ranges of SL, TL, and $W$ of males amounted to 23.5-115.6 $\mathrm{mm}, 30.6-140.2 \mathrm{~mm}$, and $0.4-43.5 \mathrm{~g}$. The SL, TL, and $W$ of females ranged from 20.7 to $127.71 \mathrm{~mm}, 27.3$ to 149.0 $\mathrm{mm}$ and 0.3 to 75.8 , respectively. The relation between SL and TL was described by equations:

$\mathrm{TL}=1.207 \mathrm{SL}+1.428 ; r^{2}=0.996(P<0.05)$ for males, $\mathrm{TL}=1.191 \mathrm{SL}+2.013 ; r^{2}=0.996(P<0.05)$ for females, and

$$
\begin{gathered}
\mathrm{TL}=1.199 \mathrm{SL}+1.721 ; r^{2}=0.996(P<0.05) \text { for both } \\
\text { sexes. }
\end{gathered}
$$

The estimated parameters for the length-weight regressions are given in Table 1. Our data indicated that both sexes showed negative allometric growth (males: $t$-student $=-3.077, n=625 ; P<0.05$; females: $t$-student $=-6.077, n=608 ; P<0.05$; sex combined: $t$-student $=-6.667, n=1233 ; P<0.05)$. ANCOVA on the log transformed values of length and weight did not detect a significant sex-based difference in the length-weight relation for this population $(F=3.237, \mathrm{DF}=1, P>0.05)$.

Length groups were formed from the standard length data of collected specimens using $2 \mathrm{~mm}$ class intervals for the length-frequency analysis. According to the Bhattacharya method, five age groups were identified (Fig. 1). There was no significant difference in length-frequency distribution between males and females (KolmogorovSmirnov, $D=0.089, P>0.05)$. Descriptive statistics of these groups were revealed by the Bhattacharya method (Table 2). The $0+$ age group ( $\hat{\jmath} 50.26 \%, q 49.30 \%$ ) was dominant in both sexes, followed by $1+, 2+, 3+$, and $4+$ age groups. Two-way ANOVA showed significant differences in class size for all age groups between males and females (age: $F=4997.9, \mathrm{DF}=4, P<0.05$; sex: $F=18.2, \mathrm{DF}=$ $1, P<0.05$; age $\times$ sex: $F=34.3, \mathrm{DF}=4, P<0.05)$. The mean SL at age and the annual linear increments of males and females are presented in Fig. 2A-B. Annual mean values of Fulton's condition factor $(K)$ are presented in Fig. 2C. In case of males, the annual mean values of $K$ showed an increasing trend, unlike in case of females, where a decreasing tendency was observed. Linear regression analysis showed that regression slopes (Fig. 2) are statistically different from $0(P<0.05)$.

The von Bertalanffy growth curves were fitted to the SL at age data for sexes both separately and in combination. The estimated parameters of Bertalanffy equations were: $L_{\infty}=138.87 \mathrm{~mm}( \pm 26.60), k=0.21( \pm 0.10), t_{0}=-0.54$ $( \pm 0.06)$ for males, $L_{\infty}=174.21 \mathrm{~mm}( \pm 30.24), k=0.17$ $( \pm 0.06), t_{0}=-0.33( \pm 0.03)$ for females, $L_{\infty}=154.01 \mathrm{~mm}$ $( \pm 24.54), k=0.19( \pm 0.01), t_{0}=-0.45( \pm 0.04)$ for all

Table 1

Length-weight relation parameters for male and female Perccottus glenii from the Rakamazi-Nagy-morotva

\begin{tabular}{ccccccc}
\hline Sex & $\mathrm{n}$ & $\mathrm{a}$ & $\mathrm{CI} 95 \%(a)$ & $b$ & CI 95\% $(b)$ & $r^{2}$ \\
\hline $\mathrm{M}$ & 625 & 0.000032 & $0.000029-0.000035$ & 2.960 & $2.935-2.985$ & 0.989 \\
$\mathrm{~F}$ & 608 & 0.000038 & $0.000034-0.000042$ & 2.921 & $2.896-2.946$ & 0.988 \\
$\mathrm{~T}$ & 1233 & 0.000035 & $0.000033-0.000037$ & 2.940 & $2.922-2.958$ & 0.989 \\
\hline
\end{tabular}

$\mathrm{M}=$ male, $\mathrm{F}=$ female, $\mathrm{T}=$ total; $n=$ number of specimens, $a=$ intercept (mean value), $b=$ slope of the regression (mean value), $\mathrm{CI}=$ confidence interval, $r^{2}=$ coefficient of determination. $P$-values were less than 0.05 in all cases. 


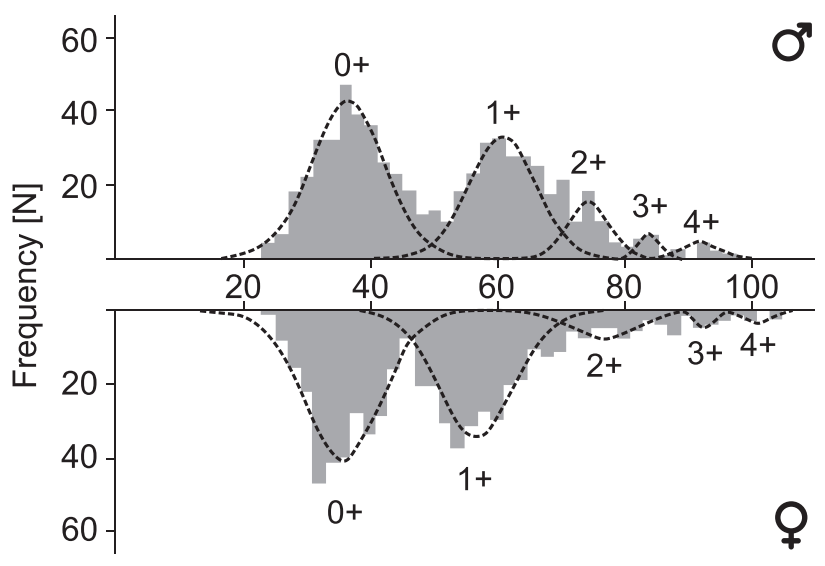

Standard length [mm]

Fig. 1. Frequency distribution of standard length (SL) of males and females of Perccottus glenii; Cells are leftopened and right-closed intervals; Dotted line stands for the fitted normal distribution estimated by the Bhattacharya method

specimens. The growth performance indices were $\Phi^{\prime}=3.61$ for males, $\Phi^{\prime}=3.71$ for females, and $\Phi^{\prime}=3.65$ for both sexes, respectively. ARSS showed no significant differences in VBGMs between the sexes $(F=1.028, P>0.05)$.

\section{DISCUSSION}

In this study the growth features of one of the most invasive freshwater fish, Amur sleeper, were investigated. This alien species is spreading aggressively in central Europe, threatening populations of native fish species. Up to now, the largest Amur sleeper reported in the literature (250 $\mathrm{mm}$ of total length, 10 years of age) was caught in the invaded area in Lake Glubokoe, Russia (Reshetnikov 2003) indicating an approximately $207.4 \mathrm{~mm}$ standard length based on the SL-TL relation determined in the presently reported study. In central Europe, the largest male $(130 \mathrm{~mm}$ standard length, 7 years of age) and female (142 $\mathrm{mm}$ standard length, 7 years of age) of Amur sleeper were reported from the Vistula River, Poland (Grabowska et al. 2011). In the population covered in our study, the largest male had 115.6 mm standard length ( 7 years of age), and the largest female had $140.2 \mathrm{~mm}$ standard length (7 years of age). The sex ratio did not differ from parity $(1 \div 1)$, similarly to the observation in the Vistula River (Grabowska et al. 2011).

Our data showed $<3.0$ calculated $b$-values indicating a negative allometric growth in both sexes with no significant differences in the SL- $W$ relation. A hypoallometric growth pattern implies the fish becomes more slender as it increases in length (Froese et al. 2011). In the above-mentioned study of Grabowska et al. (2011) an isometric growth pattern was reported for both sexes in the Vistula. Since RNM is a shallow oxbow lake with controlled and intermittent water supply from the Tisza River, different environmental conditions may cause this discrepancy in growth pattern.

Our analyses revealed that the growth rate of males in their first two years of life was more intensive than that of females, while the growth rate of both sexes became just less intensive from the third year of life (Fig. 2A). Amur
Table 2

Descriptive statistics of age groups of males and females of Perccottus glenii identified by the Bhattacharya method

\begin{tabular}{|c|c|c|c|c|c|}
\hline Sex & $\begin{array}{l}\text { Age } \\
\text { group }\end{array}$ & $\begin{array}{l}\text { Rate } \\
{[\%]}\end{array}$ & $\begin{array}{c}\text { Standard } \\
\text { length } \\
{[\mathrm{mm}]}\end{array}$ & CI $(95 \%)$ & $\begin{array}{l}\text { Separation } \\
\text { index }\end{array}$ \\
\hline \multirow{5}{*}{ o } & $1(0+)$ & 50.26 & $36.45 \pm 5.76$ & $35.80-37.10$ & - \\
\hline & $2(1+)$ & 35.93 & $60.60 \pm 5.30$ & $59.89-61.31$ & 2.62 \\
\hline & $3(2+)$ & 9.79 & $72.82 \pm 3.21$ & $71.99-73.65$ & 2.11 \\
\hline & $4(3+)$ & 2.27 & $82.76 \pm 1.68$ & $81.78-83.74$ & 2.13 \\
\hline & $5(4+)$ & 1.74 & $90.33 \pm 3.40$ & 87.99-92.67 & 2.06 \\
\hline \multirow{5}{*}{ 우 } & $1(0+)$ & 49.30 & $35.69 \pm 5.99$ & $35.01-36.37$ & - \\
\hline & $2(1+)$ & 41.93 & $56.76 \pm 5.90$ & $56.03-57.49$ & 2.44 \\
\hline & $3(2+)$ & 6.29 & $76.81 \pm 4.75$ & $75.25-78.37$ & 2.30 \\
\hline & $4(3+)$ & 1.39 & $92.69 \pm 1.49$ & $91.48-93.90$ & 2.24 \\
\hline & $5(4+)$ & 1.09 & $101.00 \pm 2.37$ & 98.69-103.31 & 2.09 \\
\hline
\end{tabular}

Standard length values are mean \pm standard deviation, CI $=$ confidence interval. Rate $=$ relative frequency of individuals found in each age group by sexes.
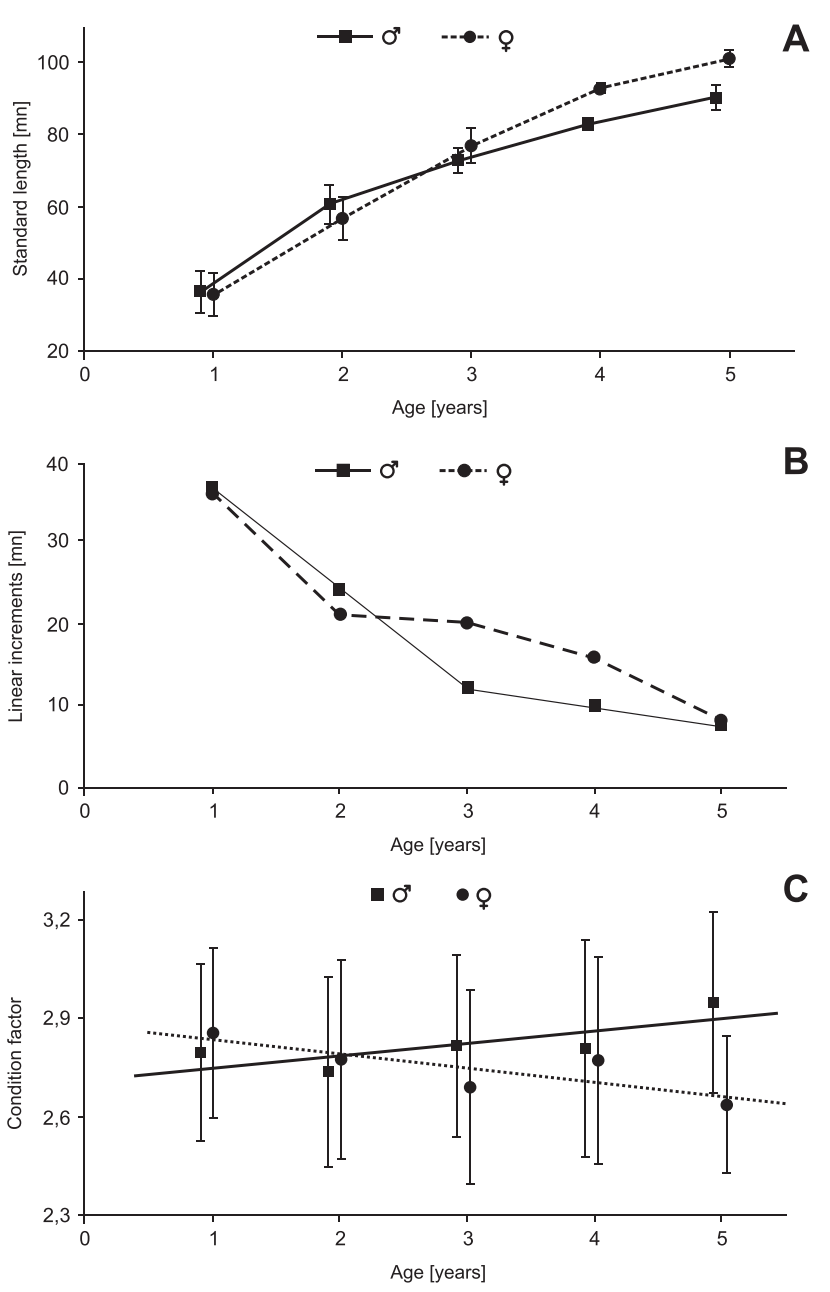

Fig. 2. Observed standard length (SL) at age (A), and changes in the annual linear increments (B), and the Fulton's condition factors $(\mathbf{C})$ for males and females of Perccottus glenii 
sleeper (both sexes), in their native area, matured about the age of $2+$ or $3+$ (Bogutskaya and Naseka 2002) while in the introduced distribution range, including the European part of Russia (Spanovskaâ et al. 1964) and Poland (Grabowska et al. 2011), females reached their maturity at the age of $1+$. Similar results were observed in a study based on aquarium experiments (Bogutskaya and Naseka 2002). In our study, well developed ovaries were found in $1+$ females during the dissection of individuals indicating earlier maturation of females. It suggests that females have to allocate energy for earlier development of gonads. The energy channelled into the gonads detracts from the somatic growth (Roff 1983, Kozłowski 2006), so females achieve smaller length due to earlier gonad development during the first two years. In contrast, the majority of males reach maturity at the age of $2+$ both in native (Nikolskij 1956) and in introduced area (Bogutskaya and Naseka 2002). The role of males in reproduction is not only the fertilisation of oocytes, but also aggressive protection of the nest and fanning the eggs with their pectoral fins, preventing oxygen deficiency of embryos (Bogutskaya and Naseka 2002). In contrast, the role of females in reproduction is only laying their eggs. Therefore, the post-maturation growth of males (from age of $2+$ ) is slower due to the energetic trade-off between reproduction and somatic growth (Lester et al. 2004, Kozłowski 2006). Our analysis of the annual linear increments revealed higher linear increment of males in their pre-mature period, but lower annual increment was observed in the post-mature life span (Fig. 2B). The higher parental investment into reproduction and the decreased feeding during the nest guarding may be major causes of this phenomenon (Grabowska et al. 2011).

The annual fluctuation in Fulton's condition factors showed a decreasing tendency in females but an increasing trend in males (Fig. 2C). Our data indicated that the higher was the annual linear increment the lower was the condition factor of the individuals by sexes (Fig. 2B-C). Due to the hypoallometric growth a spindly individual with higher linear increment had a relatively lower condition factor in the same year. The key of the evolutionary success of nest guarding males is their good condition at the end of the growth season. In the majority of cases, a larger male in good condition overwintered with lower energy deficit, could fertilize more eggs and was a more effective nest guardian because it could sustain longer period of starvation during the nest defending (Ridgway et al. 1991, Fessehaye et al. 2006, Wotton and Smith 2014). On the other hand, Amur sleeper females exhibit no parental care, they should not present high condition factor to perform successfully spawning, therefore longer but slender, spindly females have lower condition factor than robust males in their post-mature life.

Our results on growth performance parameters (based on the von Bertalanffy growth equation) suggest that the growth of Amur sleeper in RNM was relatively faster than that in the Vistula River, but there were no significant different among VBGMs for pooled data $(F=0.4425, P>$ 0.05) (Grabowska et al. 2011).

Comparison of previously published growth data of different $P$. glenii populations with our recent results implies that the growth of Amur sleeper is variable depending on the geographic range (Table 3). In general, populations in invaded areas (mainly in the former Soviet Union) grow faster than those in native range (Fig. 3). In the European part of Russia, the well established naturalized populations grew rapidly, likely due to favourable environmental conditions (e.g., favourable climate, food resources, and lack of control by natural enemies) (Table 3, Fig. 3). The growth of Amur sleeper in RNM seems to be slower in comparison with both native and introduced areas, especially after maturation. Higher investment in reproduction (development of gonads, multiple and longer spawning season, early maturation of females, parental care of males, etc.) may result in decrease in growth rate in these populations.

The most successful non-native invasive species in central Europe (especially the Ponto-Caspian gobies and the odontobutid Amur sleeper) collectively exhibit characteristic life-history traits like short maximum body length, short-life spawn, early maturation, multiple spawning events, extended breeding season, low fecundity but relatively large eggs and parental care (Erős 2005, Grabowska et al. 2011, Grabowska and Przybylski 2015). These features help them to maximize the colonizing capacity in the relatively early stage of naturalization.

Breeding season of $P$. glenii in its native range usually lasts from the end of May through June (Nikolskij 1956), while in our study we observed an extended spawning period of Amur sleeper populations in the Carpathian Basin. The spawning season of Amur sleeper lasts from April to September in the rapidly warming shallow lakes and ponds (Harka et al. 2012).

Our results revealed significant differences in growth features of Amur sleeper between males and females due to the unequal investment in reproduction. Like other invasive alien species, Amur sleeper shows characteristic life-history traits in the early stage of invasion resulting in successful colonization of the new habitat. This opportunistic strategy of Amur sleeper populations in central Europe is leading to slower growth of individuals than in other ranges, where

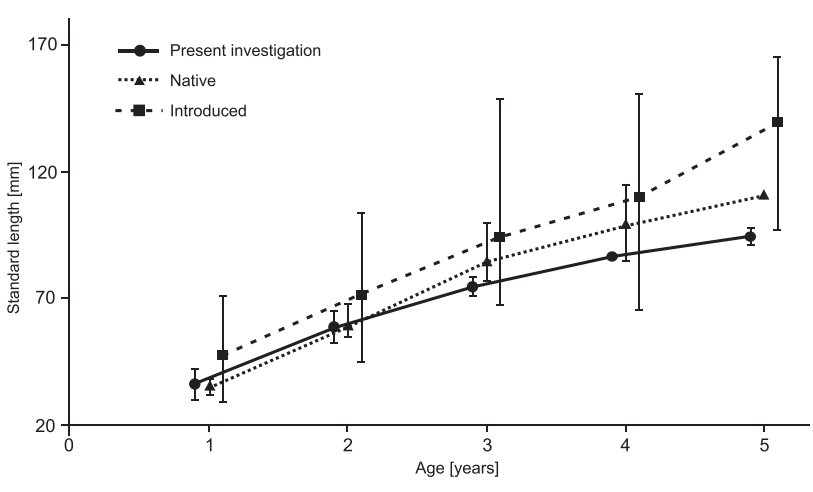

Fig. 3. Growth of Perccottus glenii in Rakamazi-Nagymorotva, Hungary (presently reported study) in comparison with mean values of standard length (SL) at age from native and other introduced range, based on Table 3; Vertical lines indicate the minimum and maximum SL at age 
Table 3

Standard lengths (SL) at age of native and introduced populations of Perccottus glenii from different areas

\begin{tabular}{|c|c|c|c|c|c|c|c|c|c|}
\hline \multirow{2}{*}{ Location } & \multirow{2}{*}{ PP } & \multicolumn{7}{|c|}{ Observed SL at age [mm] } & \multirow{2}{*}{ Reference } \\
\hline & & $0+$ & $1+$ & $2+$ & $3+$ & $4+$ & $5+$ & $6+$ & \\
\hline Lake Khanka, RU & NAT & 35 & 55 & 77 & & & & 136 & Yakovlev $1925^{\mathrm{a}}$ \\
\hline Suifun River, RU & NAT & 32 & 55 & 77 & 85 & 111 & 123 & 136 & Kirpichnikov $1945^{b}$ \\
\hline Amur River, RU & NAT & 38 & 68 & 100 & 114 & & & & Nikolskij 1956 \\
\hline Moscow region I, RU & INT & 66 & 94 & 110 & 130 & & & & Spanovskaâ et al. 1964 \\
\hline Moscow region II, RU & INT & 66 & 90 & 100 & 125 & & & & Spanovskâ̂ et al. 1964 \\
\hline Moscow region III, RU & INT & 55 & 64 & & & & & & Spanovskaâ et al. 1964 \\
\hline Moscow region IV, RU & INT & 71 & 90 & 120 & 134 & & & & Spanovskaâ et al. 1964 \\
\hline Moscow region V, RU & INT & 45 & 66 & 72 & 85 & & & & Spanovskâ̂ et al. 1964 \\
\hline Moscow region VI, RU & INT & 60 & 104 & 149 & 151 & & & & Spanovskaâ et al. 1964 \\
\hline Leningrad region, RU & INT & 29 & & 72 & 94 & & & & Kuderskiy $1982^{\mathrm{a}}$ \\
\hline Selenga River, RU & INT & 39 & 68 & 94 & 112 & 140 & 167 & 188 & Litvinov and O'Gorman $1996^{c}$ \\
\hline Penza region I, RU & INT & 47 & 65 & 96 & 112 & & & & Baklanov $2001^{c}$ \\
\hline Penza region II, RU & INT & 34 & 63 & 88 & 106 & 149 & & & Baklanov $2001^{\mathrm{c}}$ \\
\hline Bodrog River, SK & INT & 31 & 45 & 62 & 84 & & & & Koščo et al. $2003 b$ \\
\hline Komi Republic, RU & INT & & 63 & 95 & 111 & & & & Boznak 2004c \\
\hline Lake Glubokoke, RU & INT & 40 & 70 & 79 & & & & & Dgebuadze and Skomorokhov $2005^{\mathrm{c}}$ \\
\hline Lake Glubokoke, RU & INT & 55 & 71 & & & & & & Dgebuadze and Skomorokhov $2005^{\mathrm{c}}$ \\
\hline Moscow region I, RU & INT & 40 & 70 & 91 & 118 & & & & Dgebuadze and Skomorokhov $2005^{\mathrm{c}}$ \\
\hline Moscow region II, RU & INT & 50 & 82 & 108 & 122 & 164 & & & Dgebuadze and Skomorokhov $2005^{\mathrm{c}}$ \\
\hline Gusinoe Lake, RU & INT & & 70 & 110 & 140 & 165 & & & Bolonev and Pronin $2005^{c}$ \\
\hline Selenga River delta, RU & INT & & 60 & 80 & 100 & 120 & & & Bolonev and Pronin $2005^{c}$ \\
\hline Moscow region, RU & INT & 69 & 87 & 123 & & & & & Rešetnikov, unpublished data ${ }^{c}$ \\
\hline Vistula River, PL & INT & 37 & 53 & 69 & 83 & 97 & 112 & 122 & Grabowska et al. 2011 \\
\hline RNM, HU & INT & 36 & 59 & 74 & 87 & 94 & 110 & 118 & Presently reported study \\
\hline
\end{tabular}

$\mathrm{PP}=$ population, NAT = native, INT = introduced; Some references are based on a Bogutskaya and Naseka (2002), ${ }^{\mathrm{b}}$ Koščo et al. (2003b), and ${ }^{\mathrm{c}}$ Grabowska et al. (2011); HU = Hungary, PL = Poland, RU = Russia, SK = Slovakia, RNM = Rakamazi-Nagy-morotva; Bold font denotes the mean SL of 5+ and 6+ age groups are only informative; The Bhattacharya method was not applicable due to the small number of individuals of these age groups, thus these data were not used to other statistical evaluations; Mean standard length of $5+$ and $6+$ age groups were calculated based on data of 1-2 specimens; These data were not used to other statistical evaluations, but we have wanted to present there in this table (for aspect of comparability).

the species is native or already well established. Due to the irreversible influence of expanding invasive fish on native species, the continuous and systematic monitoring of ecology of these non-native species should have a priority.

\section{ACKNOWLEDGMENTS}

The authors express their thanks to colleagues (T. Abonyi, I. Bácsi, I. Czeglédi, D. Dobronoki, D. Fazekas, G. Fazekas, Á. Harka, A. Kovácsné Gábor, V. Tamás, P. Török) for assistance in the field and laboratory, and the Anglers Association of Tiszanagyfalu for permission to collect the specimens.

\section{REFERENCES}

Berg L.S. 1949. Ryby presnyh vod SSSR i sopredel'nyh stran. [Fishes of the USSR and adjacent countries.] Part 3. Izdalel'stvo Akademii Nauk SSSR, MoskvaLeningrad. [In Russian.]

Bhattacharya C.G. 1967. A simple method of resolution of a distribution into Gaussian components. Biometrics 23 (1): 115-135. DOI: $10.2307 / 2528285$

Bogutskaya E.P., Naseka A.M. 2002. Perccottus glenii Dybowski, 1877. In: Bogutskaya E.P., Naseka
A.M. (eds.) Freshwater fishes of Russia. Zoological Institute, Russian Academy of Sciences.

Chen, Y., Jackson, D.A., Harvey H.H. 1992. A comparison of von Bertalanffy and polynomial functions in modelling fish growth data. Canadian Journal of Fisheries and Aquatic Sciences 49 (6): 1228-1235.

DOI: $10.1139 / \mathrm{f} 92-138$

Copp G.H., Bianco P.G., Bogutskaya N.G., Erős T., Falka I., Ferreira M.T., Fox M.G., Freyhof J., Gozlan R.E., Grabowska J., Kováč V., MorenoAmich R., Naseka A. M., Penáz M., Povž M., Przybylski M., Robillard M., Russell I.C., Stakénas S., Šumer S., Vila-Gispert A., Wiesner C. 2005. To be, or not to be, a non-native freshwater fish? Journal of Applied Ichthyology 21 (4): 242-262. DOI: $10.1111 /$ j.1439-0426.2005.00690.x

Erős T. 2005. Life-history diversification in the middle Danubian fish fauna-a conservation perspective. Archiv für Hydrobiologie 16 (Suppl. 158): 289-304. DOI: $10.1127 / \mathrm{lr} / 16 / 2005 / 289$

Erôs T., Takács P., Sály P., Specziár A., György Á.I., Bíró P. 2008. Az amurgéb (Perccottus glenii Dybowski, 1877) megjelenése a Balaton vízgyüjtőjén. [Occurrence of Amur sleeper, Perccottus glenii 
Dybowski, 1877 in the water basin of Lake Balaton.] Halászat 101 (2): 75-77. [In Hungarian.]

Ferincz Á., Staszny Á., Weiperth A., Takács P., Urbányi B., Vilizzi L., Paulovits G., Copp G.H. 2016. Risk assessment of non-native fishes in the catchment of the largest central-European shallow lake (Lake Balaton, Hungary). Hydrobiologia 780 (1): 85-97.

DOI: $10.1007 / \mathrm{s} 10750-016-2657-2$

Fessehaye Y., El-bialy Z., Rezk M.A., Croojimans R., Bovenhuis H., Komen H. 2006. Mating systems and male reproductive success in Nile tilapia (Oreochromis niloticus) in breeding hapas: A microsatellite analysis. Aquaculture 256 (1-4): 148-158.

DOI: 10.1016/j.aquaculture.2006.02.024

Fox M.G., Copp G.H. 2014. Old world versus new world: Life-history alterations in a successful invader introduced across Europe. Oecologia 174 (2): 435-446. DOI: $10.1007 / \mathrm{s} 00442-013-2776-7$

Froese R. 2006. Cube law, condition factor and weightlength relationships: History, meta-analysis and recommendations. Journal of Applied Ichthyology 22 (4): 241-253.

DOI: $10.1111 / \mathrm{j} .1439-0426.2006 .00805 . \mathrm{x}$

Froese R., Tsikliras A.C., Stergiou K.I. 2011. Editorial note on weight-length relations of fishes. Acta Ichthyologica et Piscatoria 41 (4): 261-263.

DOI: 10.3750/AIP2011.41.4.01

Fulton T.W. 1911. The sovereignty of the sea: An historical account of the claims of England to the dominion of the British seas, and of the evolution of the territorial waters: With special reference to the rights of fishing and the naval salute. William Blackwood and Sons, Edinburgh, London, UK.

Gayanilo F.C.jr., Sparre P., Pauly D. 2005. FAOICLARM Stock Assessment Tools II (FiSAT II). Revised version. User's guide. FAO Computerized Information Series (Fisheries). No. 8. FAO, Rome.

Grabowska J., Grabowski M., Pietraszewski D., Gmur J. 2009. Non-selective predator - the versatile diet of Amur sleeper (Perccottus glenii Dybowski, 1877) in Vistula River (Poland), a newly invaded ecosystem. Journal of Applied Ichthyology 25 (4): 451-459. DOI: $10.1111 /$ j.1439-0426.2009.01240.x

Grabowska J., Pietraszewski D., Przybylski M., Tarkan A.S., Marszał L., Lampart-Kałużniacka M. 2011. Lifehistory traits of Amur sleeper, Perccottus glenii, in the invaded Vistula River: Early investment in reproduction but reduced growth rate. Hydrobiologia 661 (1): 197-210. DOI: $10.1007 / \mathrm{s} 10750-010-0524-0$

Grabowska J., Przybylski M. 2015. Life-history traits of non-native freshwater fish invaders differentiate them from natives in the central European bioregion. Reviews in Fish Biology and Fisheries 25 (1): 165-178.

DOI: $10.1007 / \mathrm{s} 11160-014-9375-5$

Hammer Ø., Harper D.A.T., Ryan P.D. 2001. PAST: Paleontological statistics software package for education and data analysis. Palaeontologia Electronica 4 (1): 9.
Harka Á. 1998. Magyarország faunájának új halfaja: az amurgéb (Perccottus glehni Dybowski, 1877). [New fish species in the fauna of Hungary: the Amur sleeper (Perccottus glehni Dybowski, 1877).] Halászat 91 (1): 32-33. [In Hungarian.]

Harka Á., Antal L., Mozsár A., Nyeste K., Szepesi Zs., Sályi P. 2012. Az amurgéb (Perccottus glenii) növekedése a Közép-Tisza vidékén. [Growth of the Amur sleeper (Perccottus glenii) in the Middle Tisza Region.] Pisces Hungarici 6: 55-58. [In Hungarian.]

Harka Á., Sallai Z., Koščo J. 2003. Az amurgéb (Perccottus glenii) terjedése a Tisza vízrendszerében. [Spreading of the Amur sleeper (Perccottus glenii) in the river system of the Tisza.] A Puszta 2001 18: 4956. [In Hungarian.]

Kati S., Mozsár A., Árva D., Cozma N.J., Czeglédi I., Antal L., Nagy S.A., Erős T. 2015. Feeding ecology of the invasive Amur sleeper (Perccottus glenii Dybowski, 1877) in central Europe. International Review of Hydrobiology 100 (3-4): 116-128. DOI: 10.1002/iroh.201401784

Koščo J., Lusk S., Halačka K., Lusková V. $2003 a$. The expansion and occurrence of the Amur sleeper (Perccottus glenii) in eastern Slovakia. Folia Zoologica 52 (3): 329-336.

Koščo J., Manko P., Miklisová D., Košuthová L. 2008. Feeding ecology of invasive Perccottus glenii (Perciformes, Odontobutidae) in Slovakia. Czech Journal of Animal Science 53 (11): 479-486.

Koščo J., Manko P., Ondrey I. 2003b. Vek a rast býčkovca hlavatého (Perccottus glenii Dybowski, 1877) v inundačných vodách Bodrogu. [Growth of Amur sleeper (Perccottus glenii Dybowski, 1877) in the inundation waters of the Bodrog River.] Natura Carpatica 44: 267-274. [In Slovakian.]

Kottelat M., Freyhof J. 2007. Handbook of European freshwater fishes. Kottelat, Cornol, Switzerland and Freyhof, Berlin, Germany.

Kozłowski J. 1996. Optimal allocation of resources explains interspecific life-history pattern in animals with indeterminate growth. Proceedings of the Royal Society of London B 263 (1370): 559-566.

DOI: $10.1098 / \mathrm{rspb} .1996 .0084$

Kozlowski J. 2006. Why life histories are diverse. Polish Journal of Ecology 54 (4): 585-605.

Le Cren E.D. 1951. The length-weight relationship and seasonal cycle in gonad weight and condition in the perch (Perca fluviatilis). Journal of Animal Ecology 20 (2): 201-219.

DOI: $10.2307 / 1540$

Lester N.P., Shuter B.J., Abrams P.A. 2004. Interpreting the von Bertalanffy model of somatic growth in fishes: The cost of reproduction. Proceedings of the Royal Society of London B 271 (1348): 1625-1631.

DOI: $10.1098 / \mathrm{rspb} .2004 .2778$

Munro J.L., Pauly D. 1983. A simple method for comparing the growth of fishes and invertebrates. Fishbyte 1: 5-6. 
Nehring S., Steinhof J. 2015. First records of the invasive Amur sleeper, Perccottus glenii Dybowski, 1877 in German freshwaters: A need for realization of effective management measures to stop the invasion. BioInvasions Records 4 (3): 223-232.

DOI: 10.3391/bir.2015.4.3.12

Nikolskij G.V. 1956. Ryby bassejnaAmura. ItogiAmurskoj ihtiologičeskoj èkspedicii 1944-1949. [Fishes of Amur River basin. Results of Amur ichthyological expedition of 1944-1949.] Izdalel'stvo Akademii Nauk SSSR, Moskva-Leningrad. [In Russian.]

Raikova-Petrova G.N., Petrov I.K., Hamwi N.I., Marinova D.M. 2011. Growth rate and condition of riffle minnow (Alburnoides bipunctatus Bloch) from the middle stream of Iskar River (Bulgaria). Acta Zoologica Bulgarica 63 (3): 295-300.

Rešetnikov A.N. 2001. Vliânie introducirovannoj ryby rotana Perccottus glenii (Odontobutidae, Pisces) na zemnovodnyh $\mathrm{v}$ malyh vodoemah podmoskov'â. [Influence of introduced fish Perccottus glenii (Odontobutidae, Pisces) on amphibians in small waterbodies of Moscow Region.] Žurnal Obŝej Biologii 62 (4): 352-361. [In Russian.]

Reshetnikov A.N. 2003. The introduced fish, rotan (Perccottus glenii), depresses populations of aquatic animals (macroinvertebrates, amphibians, and a fish). Hydrobiologia 510 (1): 83-90.

DOI: 10.1023/B:HYDR.0000008634.92659.b4

Reshetnikov A.N. 2004. The fish Perccottus glenii: History of introduction to western regions of Eurasia. Hydrobiologia 522 (1): 349-350.

DOI: 10.1023/B:HYDR.0000030060.29433.34

Reshetnikov A.N. 2013. Spatio-temporal dynamics of the expansion of rotan Perccottus glenii from west-Ukrainian centre of distribution and consequences for European freshwater ecosystems. Aquatic Invasions 8 (2): 193-206. DOI: 10.3391/ai.2013.8.2.07

Reshetnikov A.N., Ficetola G.F. 2011. Potential range of the invasive fish rotan (Perccottus glenii) in the Holarctic. Biological Invasions 13 (12): 2967-2980. DOI: $10.1007 / \mathrm{s} 10530-011-9982-1$

Reshetnikov A.N., Karyagina A.S. 2015. Further evidence of naturalisation of the invasive fish Perccotuss glenii Dybowski, 1877 (Perciformes: Odontobutidae) in Germany and necessity of urgent management response. Acta Zoologica Bulgarica 67 (4): 553-556.

Reshetnikov A.N., Schliewen U.K. 2013. First record of the invasive alien fish rotan Perccottus glenii Dybowski, 1877 (Odontobutidae) in the upper Danube drainage (Bavaria, Germany). Journal of Applied Ichthyology 29 (6): 1367-1369.

DOI: $10.1111 /$ jai.12256

Reshetnikov A.N., Sokolov S.G., Protasova E.N. 2017. Detection of a neglected introduction event of the invasive fish Perccottus glenii using parasitological analysis. Hydrobiologia 788 (1): 65-73.

DOI: $10.1007 / \mathrm{s} 10750-016-2987-0$
Ricker W.E. 1975. Computation and interpretation of biological statistics of fish populations. Bulletin of the Fisheries Research Board of Canada No. 191.

Ridgway M.S., Shuter B.J., Post E.E. 1991. The relative influence of body size and territorial behaviour on nesting asynchrony in male smallmouth bass, Micropterus dolomieui (Pisces: Centrarchidae). Journal of Animal Ecology 60 (2): 665-681. DOI: $10.2307 / 5304$

Roff D.A. 1983. An allocation model of growth and reproduction in fish. Canadian Journal of Fisheries and Aquatic Sciences 40 (9): 1395-1404. DOI: $10.1139 / \mathrm{f} 83-161$

Spanovskaâ V.D., Savvaitova K.A., Potapova T.L. 1964. Ob izmienčivosti rotana (Perccottus glehni Dyb., fam. Eleotridae) pri akklimatizacii. [Variation of Amur sleeper (Perccottus glehni Dyb., fam. Eleotridae) in acclimatization.] Voprosy Ihtiologii 4 (4): 632-643. [In Russian.]

Tesch F.W. 1968. Age and growth. Pp. 93-123. In: Ricker W.E. (ed.) Methods for assessment of fish production in freshwaters. Blackwell Scientific Publications, Oxford, UK.

Takács P., Czeglédi I., Ferincz Á. 2015. Amurgéb (Perccottus glenii) a Dráva vízgyüjtőjéről. [First data of Amur sleeper (Perccottus glenii) from the Hungarian Drava system.] Halászat 108 (1): 15. [In Hungarian.]

Takács P., Vitál Z. 2012. Amurgéb (Perccottus glenii Dybowski, 1877) a Duna mentén. [New Amur sleeper (Perccottus glenii Dybowski, 1877) locality beside the Hungarian Lower Danube section.] Halászat 105 (4): 16. [In Hungarian.]

Vilà M., Basnou C., Plšek P., Josefsson M., Genovesi P., Gollasch S., Nentwig W., Olenin S., Roques A., Roy D., Hulme P.E., DAISIE partners 2010. How well do we understand the impacts of alien species on ecosystem services? A pan-European cross-taxa assessment. Frontiers of Ecology and Environment 8 (3): 135-144. DOI: $10.1890 / 080083$

von Bertalanffy L. 1934. Untersuchungen über die Gesetzlichkeit des Wachstums. I. Allgemeine Grundlagen der Theorie; mathematische und physiologische Gesetzlichkeiten des Wachstums bei Wassertieren. Archiv für Entwicklungsmechanik der Organismen 131: 613-652.

Wotton R.J., Smith C. 2014. Reproductive biology of teleost fishes. Wiley-Blackwell, Oxford, UK.

Zar J.H. 2010. Biostatistical analysis. 5th edn. Prentice Hall, Upper Saddle River NJ, USA.

Živkov M.T., Trichkova T.A., Raikova-Petrova G.N. 1999. Biological reasons for the unsuitability of growth parameters and indices for comparing fish growth. Environmental Biology of Fishes 54 (1): 67-76. DOI: 10.1023/A:1007425005491

Received: 17 March 2016

Accepted: 13 January 2017

Published electronically: 31 March 2017 